\title{
REVIEW
}

\section{BIOLOGICAL CONTROL OF MYCOTOXIN-PRODUCING MOLDS}

\author{
Controle biológico de fungos de armazenamento produtores de micotoxinas \\ Flávio Henrique Vasconcelos de Medeiros ${ }^{1}$, Samuel Julio Martins², Tiago Domingues Zucchi \\ Itamar Soares de Melo $^{3}$, Luis Roberto Batista ${ }^{4}$, José da Cruz Machado $^{5}$
}

\begin{abstract}
Mycotoxins are produced by the secondary metabolism of many fungi and can be found in almost $25 \%$ of the world's agricultural commodities. These compounds are toxic to humans, animals, and plants and therefore, efforts should be made to avoid mycotoxin contamination in food and feed. Besides, up to $25 \%$ of all harvested fruits and vegetables are lost due to storage molds and/ or mycotoxin contamination and many methods have been applied to mitigate these issues, but most of them rely on the use of fungicides. Although chemicals are often the first defensive line against mycotoxigenic fungi, the indiscriminate use of fungicides are awakening the public perception due to their noxious effects on the environment and human/animal health. Thus, there is an increasing public pressure for a safer and eco-friendly alternative to control these organisms. In this background, biological control using microbial antagonists such as bacteria, fungi and yeasts have been shown to be a feasible substitute to reduce the use of chemical compounds. Despite of the positive findings using the biocontrol agents only a few products have been registered and are commercially available to control mycotoxin-producing fungi. This review brings about the up-to-date biological control strategies to prevent or reduce harvested commodity damages caused by storage fungi and the contamination of food and feed by mycotoxins.
\end{abstract}

Index terms: Biocontrol, microbial antagonists, postharvest decay, food safety.

\section{RESUMO}

As micotoxinas são produzidas pelo metabolismo secundário de várias espécies de fungos e podem ser encontradas em quase $25 \%$ das commodities agrícolas. Esses compostos são tóxicos a humanos, animais e plantas e, portanto, esforços para evitar a contaminação de micotoxinas em alimentos e rações devem ser feitos. Além disso, até $25 \%$ das frutas e legumes em pós-colheita são perdidos em decorrência do ataque de fungos de armazenamento e/ou contaminações por micotoxinas. Vários métodos têm sido aplicados para mitigar os problemas de micotoxinas, mas a maioria deles se baseia no uso de fungicidas. Embora os produtos químicos sejam, muitas vezes, a primeira estratégia de defesa contra fungos micotoxigênicos, o uso indiscriminado de fungicidas vem despertando a percepção pública, em razão de seus efeitos nocivos sobre o meio ambiente e à saúde humana/animal. Assim, existe uma crescente pressão pública em busca de alternativas mais segura e não nocivas ao meio ambiente para controlar estes organismos. Nesse contexto, o controle biológico utilizando antagonistas microbianos, tais como bactérias, fungos e leveduras têm mostrado ser um substituto viável para reduzir a utilização de produtos químicos. Apesar dos resultados positivos, usando os agentes de controle biológico, poucos produtos apenas foram registrados e estão comercialmente disponíveis para controlar fungos produtores de micotoxinas. Esta revisão traz estratégias de controle biológico para evitar ou reduzir danos em commodities agrícolas causadas por fungos de armazenamento e a contaminação de alimentos e rações por micotoxinas.

Termos para indexação: Agentes de biocontrole, microrganismos antagonistas, perda em pós-colheita, segurança alimentar.

(Received in july 30, 2012 and approved in august 28, 2012)

\section{INTRODUCTION}

Postharvest diseases, caused by storage moulds, account for considerable levels of postharvest losses. Conservative estimates consider that about $20-25 \%$ of the harvested fruits and vegetables are lost due to postharvest diseases even in developed countries (SPADARO; GULLINO, 2004). In developing countries, postharvest losses are often more severe due to inadequate storage and transportation facilities (SHARMA; SINGH; SINGH, 2009), which often makes the environment more favorable to the storage fungal development. Furthermore, most of these fungi may produce dangerous metabolites, namely mycotoxins, often acutely toxic to humans, animals, and plants (LACKNER; MARTINEZ; HERTWECK, 2009;

\footnotetext{
1Universidade Federal de Lavras/UFLA-Departamento de Fitopatologia/DFP_Cx.P. 3037-37200-000-Lavras -MG -Brasil -flaviomedeiros@dfp.ufla.br 2Universidade Federal de Lavras/UFLA - Lavras - MG - Brasil

${ }^{3}$ Empresa Brasileira de Pesquisa Agropecuária/EMBRAPA - Meio Ambiente - Jaguariúna - SP - Brasil

${ }^{4}$ Universidade Federal de Lavras/UFLA - Departamento de Ciência dos Alimentos/DCA - Lavras - MG - Brasil

${ }^{5}$ Universidade Federal de Lavras/UFLA - Departamento de Fitopatologia/DFP - Lavras - MG - Brasil
} 
PROCTOR, et al., 2009; REVERBERI, et al., 2010). Some mycotoxins are present only in the fungus whereas others are excreted, in some cases, in foods and feeds (FILTENBORG; FRISVAD; THRANE, 1996). Mycotoxin contaminations can occur in the field, before or after the harvest, and during the transfer and product storage (CALDAS; SILVA; OLIVEIRA, 2002). Also, as these compounds are highly resistant to physical and chemical treatment, once mycotoxins are found in food, generally, persist during the processing and storage (SCOTT et al., 1992). Thus, to prevent or, at least minimize the production losses and to obtain stored food products of high quality for market place, strategies to control storage fungi as well as mycotoxin productions must be done.

Although synthetic fungicides are the primary means by which postharvest diseases is controlled (KORSTEN, 2006; DAL BELLO et al., 2008), currently the global trend is turned to safer and eco-friendly alternative approaches (JANISIEWICZ; KORSTEN, 2002; MARI; NERI; BERTOLINI, 2007; SHARMA et al., 2009). One of these possibilities is the use of antagonistic microorganisms to control mycotoxigenic fungi. This method (biological control) have been applied during the last decades (WELLER, 1988) and substantial progress in the management of these pathogens and their mycotoxins have also been achieved (JANISIEWICZ; KORSTEN, 2002; SPADARO; GULLINO 2004; KORSTEN, 2006; VELMOUROUGANE et al., 2011).

\section{MYCOTOXINS: A SECONDARY METABOLITES OF STORAGE FUNGI}

Many of the storage fungi may produce a plenty of natural products, often called secondary metabolites, which include pigments, toxins, plant growth regulators, antibiotics (CALVO et al., 2002; PROCTOR et al., 2009). Some of these fungal compounds have beneficial importance to mankind, such as the antibiotic penicillin - a secondary metabolite from Penicillium notatum which is still widely used nowadays, though many bacterial species are now resistant to it. On the other hand, others secondary metabolites, namely mycotoxins, are dangerous and often present noxious effect to eukaryotes, including humans, animals, and plants (LACKNER; MARTINEZ; HERTWECK, 2009; PROCTOR et al., 2009; REVERBERI et al., 2010).

Mycotoxin (from Greek "mykes", fungus, from Latin "'toxicum", poison) is produced during the fungal growth and can be found in the hyphae and spores of these organisms (ZUCCHI; MELO, 2009; KÖPPEN et al., 2010). If ingested, mycotoxins may cause acute or chronic disease episodes, termed mycotoxicosis (MILICEVIC; SKRINJAR, BALTIC, 2010; KÖPPEN et al., 2010).

Foods are usually the preferred via for mycotoxin contamination and once consumed the exerted toxic effects are induced (KÖPPEN et al., 2010). Mycotoxin long-term exposure has also been related to several mycotoxicosis, such as carcinogenic, mutagenic, teratogenic, estrogenic, hemorrhagic, immunotoxic, nephrotoxic, hepatotoxic, dermotoxic neurotoxic and immunosuppressive (RICHARD, 2007; MILICEVIC; SKRINJAR, BALTIC, 2010).

Decontamination of food or feed are extremely difficult (RICHARD, 2007) and to avoid medical or veterinary problems usually the contaminated commodities or byproducts are destroyed.

\section{Mycotoxins background}

History facts of outbreaks, deaths, and losses involving the presence of mycotoxins date the Middle Ages. The oldest recognized mycotoxicosis of humans is the ergotism. This condition is the direct result of the consumption of products made with grains contaminated with ergotoxin - produced by the sclerotia of Claviceps purpurea (CAST, 2003). The ergotism can cause convulsion due to serotonergic stimulation of central nervous system or gangrenes of acral parts of the human body (HULVOVÁ et al., 2012). It reached epidemic proportions in central Europe, where thousands of people were mutilated and killed. Ergotism was also known as ignis sacer (sacred fire) or St. Anthony's fire, because at the time it was thought that a pilgrimage to the shrine of St. Anthony would bring relief from the intense burning sensation experienced (PERAICA et al., 1999; RICHARD, 2007).

Nevertheless, the magnitude of the fungal contamination problem began to be appreciated during World War II. At that time, it was noted that the consumption of moldy grain led to necroses of the skin, hemorrhage, liver and kidney failure, and death in numerous humans and animals (AGRIOS, 2005). For instance, during the wartime winter of 1940 in the USSR many people died after eating grain poorly stored and highly contaminated with mycotoxins (SCHUSTER; MARX; RATHAUPT, 1993). Nevertheless, although cause and effect of contaminated food ingestion could be correlated, there was no report addressing these symptoms to fungal secondary metabolites.

Consequently, the most famous episode involving mycotoxicosis was the "turkey X disease" that occurred in England in 1960, in which more than 100,000 turkeys died without any apparent reason. Posteriorly, this disease was related to the peanuts contained in the turkey feed (ASAO et al., 1963) and its cause was attributed to a 
secondary metabolite produced by Aspergillus flavus, aflatoxin (PAPP et al., 2002). Indeed, it was only after this episode that the scientific community has begun to give importance to the hazardous properties of fungal metabolites. Furthermore, from all known mycotoxins, aflatoxin is still considered the worst carcinogen compound produced by microorganisms (SHENASI; AIDOO; CANDLISH, 2002).

\section{What kind of mycotoxins can be found in the food commodities?}

Currently, more than 500 different mycotoxins have been discovered and this number do not stop increasing. Many mycotoxins are classified as polyketides, i.e. bioactive secondary metabolites synthetized as fatty acids (HOPWOOD; SHERMAN, 1990). Among the most economically and toxicologically important mycotoxins that pose greatest potential risk to human and animal health as food and feed contaminants are: aflatoxins, trichothecenes, fumonisins, zearalenone, ochratoxin, patulin, and certain ergot alkaloids (CAST, 2003; BENNETT; KLICH, 2003; RICHARD, 2007; KÖPPEN et al., 2010). Economic losses due to decrease of productivity have been estimated around one billion dollar/year, and over US\$ 500 million to mitigate the damage of only three mycotoxins: aflatoxins, fumonisins and trichothecenes (BHATNAGAR et al., 2006).

Mycotoxins are produced by a large number of fungal species and some are able to produce more than one mycotoxin (Table1). Also, some mycotoxins can be produced by more than one species (HUNSSEIN; BRASEL, 2001).

\section{REGULATIONS FOR MYCOTOXINS AROUND THE WORLD}

Since the discovery of aflatoxins, the scientific community has been attempting to limit mycotoxin contamination in foods and feeds (REVERBERI, et al., 2010). Regulations relating to mycotoxins have been established in many countries to protect the consumer from the harmful effects of these compounds (MILIÆEVIÆ; SKRINJAR; BALTIC, 2010). Virtually all countries with fully developed market economies have established regulations for mycotoxins whilst many developing countries, where subsistence farming is significant, the maximum limits of mycotoxins were not regulated yet (Figure 1; CAST, 2003).

During a long time, mycotoxins concentrations were not regulated in Brazil. However, due to a pressure increase from foreign consumers for food free of mycotoxins, Brazilian government has regulated the maximum limits for aflatoxin in food and feeds (Table 2).
Although aflatoxin is still the only regulated mycotoxin in Brazil: $20 \mu \mathrm{g} . \mathrm{kg}^{-1}$ for total aflatoxin in feed and $30 \mu \mathrm{g} . \mathrm{kg}^{-1}$ for aflatoxin $\mathrm{B}^{1}+\mathrm{G}^{1}$ in food; (CALDAS; SILVA; OLIVEIRA, 2002), other country's regulations have presented a lower tolerance for this mycotoxin. For instance, values for total aflatoxins found in food vary from $1 \mu \mathrm{g} . \mathrm{kg}^{-1}$ (Bosnian) to $10 \mu \mathrm{g} . \mathrm{kg}^{-1}$ (France) (CREPPY, 2002). Also, some regulatory policies are greatly developed as shown by countries which regulate more than one mycotoxin (Table 2). Furthermore, according to Fao, 2003 data, on a worldwide basis, at least 99 countries regulated mycotoxins for food and/or feed in 2003 representing an increase of approximately 30 percent compared to 1995 . The total population in these countries represents approximately $87 \%$ of the inhabitants of the world. This number was $77 \%$ in 1995 . The increase in 2003 is due a slight increase in coverage in Latin America and Europe, and more significant increases in Africa and Asia/Oceania. Nevertheless, currently still $13 \%$ of the inhabitants of the world live in a region where no known mycotoxin regulation is in force. Thus, it is important the use of safe methods of control of mycotoxin-producing fungi to allow the marketing of healthy products without risk to human and animal health (FOOD AND AGRICULTURE ORGANIZATION - FAO, 2003).

\section{BIOLOGICAL CONTROL}

Currently, over $25 \%$ of the world's agricultural commodities are estimates to be contaminated with mycotoxins to a certain degree (STEPIEN et al. 2007 cited by KÖPPEN et al., 2010). This serious issue has been focus of several strategies to mitigate the concentration of mycotoxins in food. The main strategy includes the use of fungicides (EDWARDS, et al., 2001) which is also considered the primary means by which postharvest diseases are controlled (SPADARO; GULLINO, 2004; KORSTEN, 2006; DAL BELLO et al., 2008). Besides, currently many reasons - public perception that pesticides are harmful to human health and the environment (JANISIEWICZ; KORSTEN, 2002), limited efficacy for the development of pathogen resistance (LIMA et al., 2006; BRODERS et al., 2007), and the public demand for produce food free of synthetic pesticides (SIPICZKI, 2006) - have been requesting to replace the synthetic chemicals use to a safer and cleaner alternative approach. In this background, biological control using antagonistic microorganisms has been an emergent alternative to efficiently manage storage fungi and mycotoxins production and hence, reducing the use of chemical compounds (JANISIEWICZ; KORSTEN, 2002; SPADARO; GULLINO 2004; KORSTEN, 2006; VELMOUROUGANEet al., 2011). 


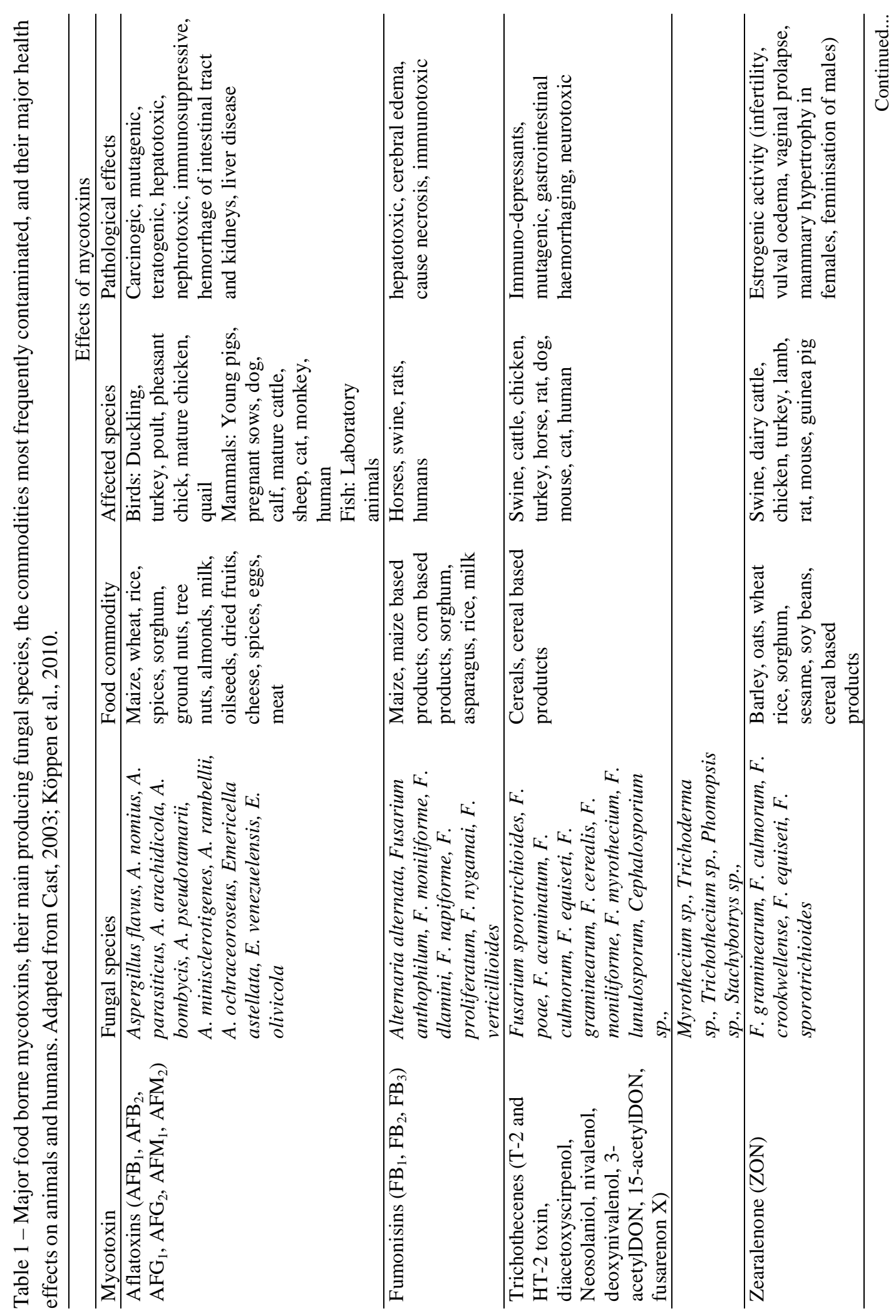

Ciênc. agrotec., Lavras, v. 36, n. 5, p. 483-497, set./out., 2012 


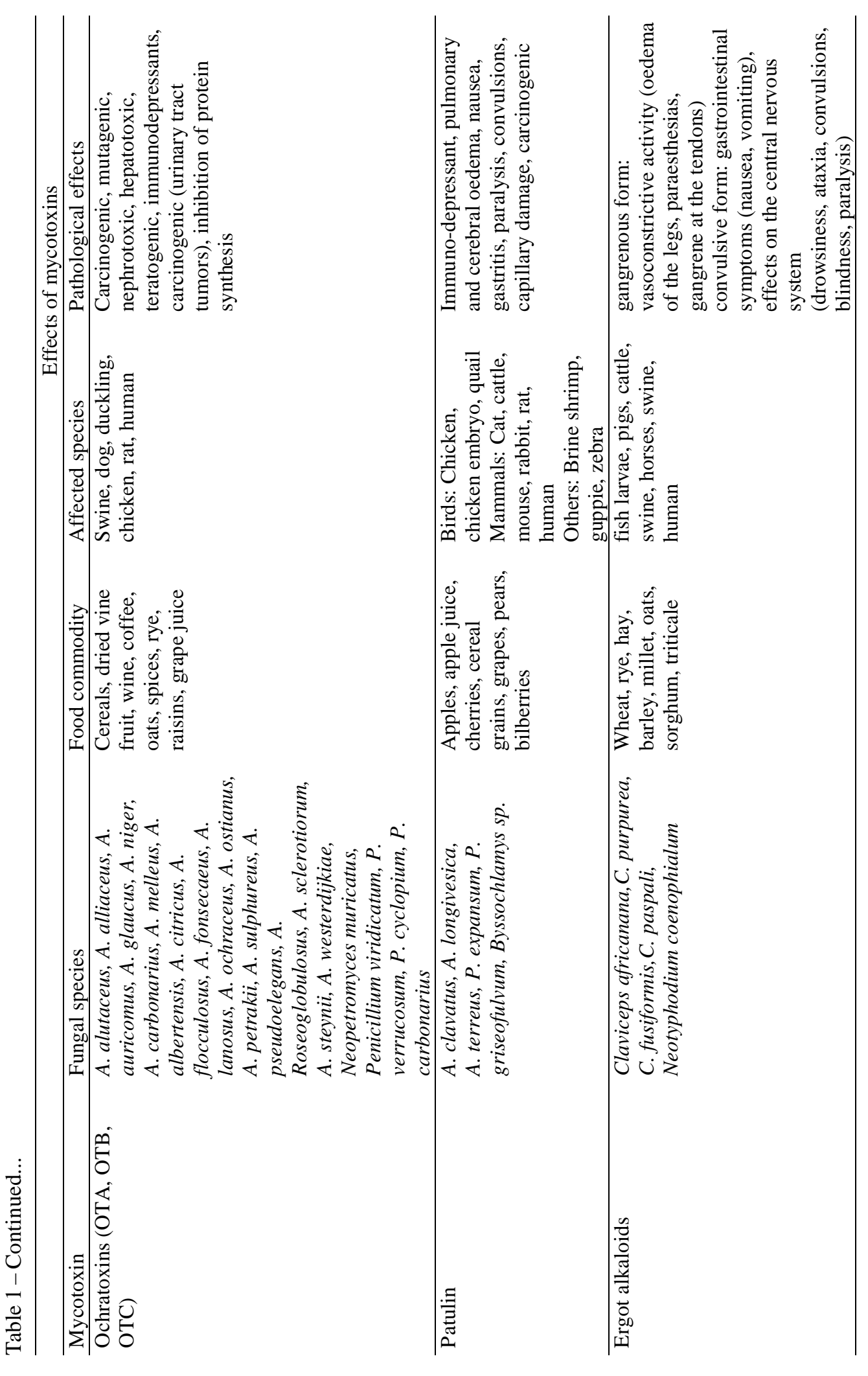

Ciênc. agrotec., Lavras, v. 36, n. 5, p. 483-497, set./out., 2012 


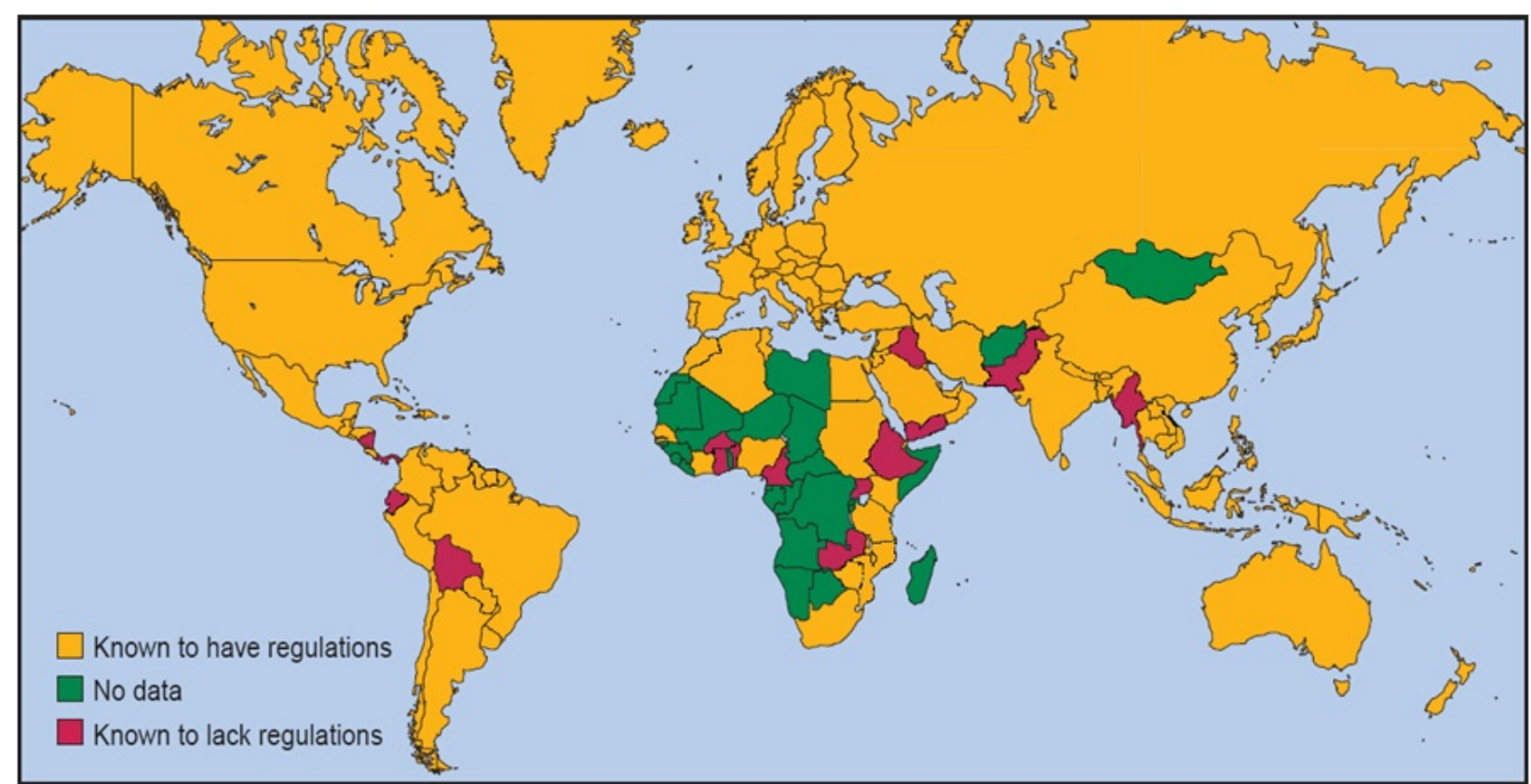

Figure 1 - Counties known to regulate mycotoxins in food and feed (yellow), those where it is unknown whether regulations exist (green), and nations known to have no specific regulations (red) (FAO, 2004). Modified from Cast, 2003 .

Table 2 - Maximum limits for mycotoxins concentrations in food.

\begin{tabular}{|c|c|c|c|}
\hline Mycotoxin & Countries & $\begin{array}{l}\text { Maximum limits } \\
\left(\mu \mathrm{g} \cdot \mathrm{kg}^{-1} \text { or } \mu \mathrm{g} \cdot \mathrm{l}^{-1}\right)\end{array}$ & Food \\
\hline Aflatoxin $\mathrm{B}_{1}$ & Belgium & 5 & All \\
\hline Aflatoxin $\mathrm{B}_{1}+\mathrm{G}_{1}$ & Brazil & 30 & All \\
\hline \multirow{4}{*}{ Aflatoxin $B_{1}+B_{2}+G_{1}+G_{2}$} & Belgium & 5 & Peanut \\
\hline & Brazil & 20 & Animal feed \\
\hline & France & 10 & All \\
\hline & USA & 20 & All \\
\hline \multirow{4}{*}{ Alflatoxin $\mathrm{M}_{1}$} & Belgium & 0.05 & Milk \\
\hline & France & 0.03 & Milk \\
\hline & Russia & 0.5 & Milk \\
\hline & USA & 0.5 & Milk \\
\hline Deoxynivalenol & Russia & 1000 & Grains \\
\hline \multirow{2}{*}{ Ochratoxin A } & Denmark & 5 & Grains \\
\hline & France & 5 & Swine feed \\
\hline \multirow{2}{*}{ Zearelone } & France & 200 & Grains and vegetal oils \\
\hline & Russia & 1000 & Grains and vegetal oils \\
\hline Toxin $\mathrm{T}_{2}$ & Russia & 100 & All \\
\hline
\end{tabular}

Source: modified from Creppy (2002).

Ciênc. agrotec., Lavras, v. 36, n. 5, p. 483-497, set./out., 2012 
Although many useful biocontrol agents were first identified through in vitro inhibition tests (i.e., evaluating inhibition of a target pathogen on an agar medium), several researchers have reported no correlation between in vitro inhibition tests and field performance of biocontrol agents (FRAVEL, 2005). This difference is usually explained by various environmental conditions which may affect the antagonist performance (COTTY; MELLON, 2006) or laboratory conditions may artificially favour the antagonist (WELLER, 1988). The trend currently seems to drift through screening procedures that simulate conditions under which the agent will be used (ABRAHAM; LAING; BOWER, 2010; ZHANG et al., 2010; MANSO; NUNES, 2011).

Recently, the number of the biocontrol products available at the market is incresing. Some examples of few products commercially available may be found at the the table 3 .

Despite of the increasing of this number, these products still represent only about $1 \%$ of agricultural chemical sales (FRAVEL, 2005). In near future is expect to find new registrations of biofungicides to control storage mould and mycotoxins.

\section{Sources of antagonists}

There are a variety of microrganisms which may be used as biocontrol agents against mycotoxigenic fungi that include different species of yeasts, fungi, and bacteria. Due to the positive findings regarding the use of these microbial antagonists, biocontrol agents have been gaining popularity worldwide (BONATERRA et al., 2003; KORSTEN, 2006; SARAVANAKUMAR et al., 2009; DE CAL et al., 2009; VELMOUROUGANE et al., 2011, SAGAHÓN et al., 2011).

According to Wilson and Wisniewski (1994) cited by Spadaro and Gullino (2004), the major characteristics of an ideal antagonist are: genetic stability, efficacy at low concentrations and against a wide range of pathogens on various fruit products, simple nutritional requirements, survival in adverse environmental conditions, growth on cheap substrates in fermenters, lack of pathogenicity for the host plant and no production of metabolites potentially toxic to humans, resistance to the most frequently used pesticides and compatibility with other chemical and physical treatments.

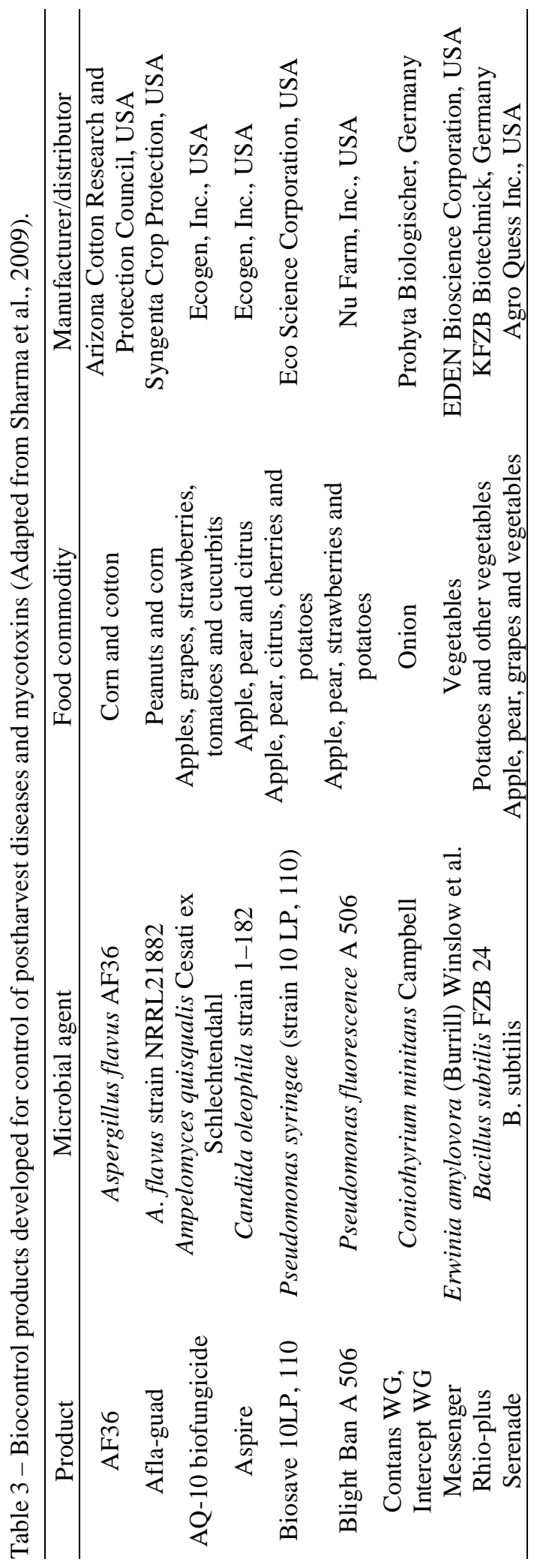

Ciênc. agrotec., Lavras, v. 36, n. 5, p. 483-497, set./out., 2012 
Based on these traits, yeasts seems to be an excellent candidate for biocontrol agents and therefore, researches have been focused on their isolation, selection and potential use for controlling phytopathogenic fungi (SIPICZKI, 2006; ABRAHAM; LAING; BOWER, 2010; LAHLALI, 2011; MANSO; NUNES, 2011). Moreover, yeasts inherent characteristics such as fast growth, fruit surface colonization and deprive nutrients from pathogens (through competition) have placed these organisms as one of the most suitable biocontrol agents (RICHARD; PRUSKY, 2002).

Information on the mechanism(s) of action by which antagonists suppress postharvest disease is still incomplete mainly due to the difficulties faced during the study of the complex interactions between host, pathogen, antagonist and other microorganisms present (SPADARO; GULLINO, 2004). However, several possible biocontrol mechanisms have been suggested including production of antibiotics, lytic enzymes, direct parasitism, induction of resistance in the host tissue, competition for nutrients and space. Yet competition for nutrients and space is most widely accepted mode action of the antagonists (SHARMA; SING; SING, 2009).

\section{Where to look for antagonists?}

Virtually any place is a potential reservoir for new biocontrol antagonists. However, the prefered niche for survey and screening of these organisms is usually healthy commodities in the storage, orchard, and untreated fields (BAKER; COOK, 1974). If these places have had a history of mycotoxigenic fungi contamination the success of selection may be enhanced due to a natural selection of organisms which could compete with the pathogen. For instance, yeasts were isolated from aflatoxin contaminated areas and positive antagonistic effect in decreasing the levels of norsolorinic acids (an aflatoxin precursor) was observed in vitro (HUA; BAKER; FLORES-ESPIRITU, 1999). In general, the grain commodities phylloplane is the preferred location for antagonists screening as it is considered a natural source of occurrence (JANISIEWICZ; KORSTEN, 2002). Many other examples can be found in the literature and probably the ultimate success for biocontrol programs depends on the methodology applyied in this search (FRAVEL, 2005). Selective isolation requirements should be taken into account to isolate different groups of antagonists and therefore, several methodologies have been proposed (BAKER; COOK 1974; SCHISLER; SLININGER 1997).

The antagonists may also come from other closely related or unrelated sources like the soil that has also been an abundant and diverse source of antagonists (MOTOMURA et al., 1996; JUNG-IL; HONG; KANG, 2000; JANISIEWICZ; KORSTEN, 2002; SAGAHÓN et al., 2011), from collections of microorganisms (LAITILA et al., 2007) or microorganisms that are involved in the production of fermented foods (PUSEY, 1991). These others sources may also yield effective antagonists (JANISIEWICZ; KORSTEN, 2002).

Furthermore, biocontrol agent mode of action, mainly antibiotics, have driven researches for surveying the bacterial diversity in a huge variety of environmental niches in which the extreme environment conditions (high pressure, salinity, temperature or aridity and low tempertatures) have recently increased in importance. Hypothetically, in these extreme conditions the organism may evolve to unique biosynthetic pathways which may lead to exclusives traits. This hypothesis have been corroborate in the vast literature regarding to description of new species from these areas (ZUCCHI et al., 2012a,b) or novel biocompounds produced by these organisms (GOODFELLOW et al., 2012).

\section{DELIVERY SYSTEMS FOR MICROBIAL ANTAGONISTS}

Mould and mycotoxin contamination may occur at any stage in the food and feed production chain: before harvest, at harvesting, or in storage (KÖPPEN et al., 2010). Therefore, after promising antagonists are selected it is necessary to search for strategies of delivery which applies it effectively for controlling or suppressing the pathogen and consequently their mycotoxin production. Basically, microbial antagonists may be delivery through two main ways: at preharvest or post-harvest stage (CAST 2003; SHARMA; SINGH; SINGH, 2009).

\section{Preharvest delivery}

The preharvest delivery strategy aims to prevent the development of fungi already in the field and hence their mycotoxin production. A current successful example is the use of the competitive nontoxigenic strains of Aspergillus flavus. This strategy is based on the competition between the toxigenic and nontoxigenic strains to exclude naturally the toxigenic strains in the same niche and compete for crop substrates (YIN et al., 2008). Some field experiments in different crops have demonstrated significant reductions in the aflatoxin contamination, values which correspond to 70-90\% (DORNER, 2004; DORNER, 2008; DORNER, 2009). Two products have been registered as biopesticides to control aflatoxin. One is called AF-36 based on the nontoxigenic strain A. flavus AF36 for 
control of aflatoxin in cottonseed. The second one is the Afla-Guard based on the nontoxigenic strain A. flavus NRRL21882 for aflatoxin control on corn (field, sweet, and popcorn) and peanuts (ISAKEIT, 2012).

\section{Postharvest delivery}

These second approach of delivery lies in two ways: 1) suppressing the pathogens, in this time after harvest and 2) through the mycotoxin decontamination by the application of microorganism antagonists.

Pathogens may be suppressed by microbial cultures which can be applied either as postharvest sprays or as dips in an antagonist's solution (IRTWANGE, 2006). The dip treatment containing a yeast suspension (Saccharomyces cerevisiae) was used in coffee postharvest, during its processing, and resulted in a significant reduction of total mould incidence (Aspergillus niger, Aspergillus ochraceus) and ochratoxin A contamination without affecting the cup quality (VELMOUROUGANE et al., 2011). Similarly, a significant reduction on the production and accumulation of aflatoxins by $A$. parasiticus in peanuts was observed after the grains were treated with a Streptomyces suspension (ZUCCHI et al., 2008).

Studies have demonstrated that mycotoxin decontamination can be reached using some yeasts, bacteria or fungal enzymes which degrade mycotoxins into non-toxic compounds and therefore, reduce the harmful effects of mycotoxins (EUROPEAN FOOD SAFETY AUTHORITY-EFSA, 2009). For instance, the yeast Trichosporon mycotoxinivorans can detoxify the zearalenone (VEKIRU et al., 2010) and ochratoxin. The latter is detoxified by the cleavage of the phenylalanine moiety to form the derivate ochratoxin $\alpha$, a virtually nontoxic metabolite compared to the parent compound (SCHATZMAYR et al., 2006). Due to the fact that $T$. mycotoxinivorans can be fermented, concentrated, freezedried, and stabilized without losing its deactivating capacity, its utilization in postharvest delivery as a feed additive for ochratoxin and/or zearalenone detoxification seems to be feasible alternative (CHAYTOR, et al., 2011).

Furthermore, an interesting trait for controlling mycotoxins in postharvest conditions, which may also be exploited, is the capacity of some compounds-producing actinomycetes that block the mycotoxin biosynthetic pathway. This recent new research line has demonstrated promising results to control aflatoxin contamination (SAKUDA et al., 1996). Streptomyces is the preferred chosen actinomycete and some compounds (aflastatin A and B; Blasticidin A and dioctatin A) have prevented the aflatoxin production without inhibition the fungus growth (SAKUDA et al, 1999; SAKUDA et al., 2000a, b; YOSHINARI et al., 2007). Since these compounds have not interfered in the fungal development, the treated fungus may confer an extra protection by niche competition against further infections.

\section{HOW TO ENHANCE THE EFFICACY OF BIOLOGICAL ANTAGONISTS?}

Although the vast progress achieved on the biological control of postharvest diseases during the last decades, difficulties can be arised in order to obtain antagonistic strains which alone show a broad spectrum of activity against a variety of mycotoxigenic pathogens. Because of that, instead of using only one isolate the trend commonly used nowadays is applying the microbial agent in a consortium with another approach. This strategy can greatly enhance the biocontrol efficaciness and some of these approaches are discussed below.

\section{Biological control and the good agricultural practices}

The first and logical step to manage phytopathogen contamination is a good agricultural practice in the field and at the storage. Some of these practices rely on the careful selection of crop material to sow as well as the time to harvest (WILSON et al., 2006; BRANDINO et al., 2009). In general, late crops are most likely to develop mycotoxin contamination issues. Cereals, coffee beans, fruits and seeds should be dried immediately after the harvest. Moreover, attention must be taken on the temperature and moisture at storage conditions (CAST, 2003). For other commodities, i.e. maize grains, the selection of hybrids, plant density, time of planting, and insect control may have an influence on toxin contamination (MAGAN; ALDRED, 2007). Some factors affecting fungi and mycotoxin occurrence in the food chain are given bellow:

- Biological factors: susceptible crop and compatible toxigenic fungus;

- Environmental factors: temperature, moisture, mechanical injury and insect/bird damage;

- Harvesting: crop maturity, temperature, moisture and contaminant detection;

- Storage: temperature, moisture and contaminant detection;

- Distribuition: contaminant detection and diversion.

\section{Antagonist mixtures}

An effective biological control based on a mixture of several complementary and non-competitive antagonists 
usually present more chances to success than a control based on only one single microorganism (SPADARO; GULLINO, 2004). Sharma et al. (2009) pointed out several advantages for using mixtures of microbial antagonists, such as:

- Widening the spectrum of phytopathogens targets;

- Decreasing the efficacy loss due to adverse environmental conditions;

- Exploring more than one mechanism of control;

- Combination of different biocontrol traits without the transfer of exogenous genes through genetic transformation.

For instance, a broader spectrum of pathogens on apple was controlled when microbial antagonists were applied in mixtures instead of use individual microbial strains (CALVO et al., 2003; CONWAY et al., 2005). Similarly, a decrease in the aflatoxin concentration from 75 to $99.9 \%$ was observed in peanut fields using a misture of nontoxigenic mutants of $A$. flavus and $A$. parasiticus (DORNER et al., 1998). Both examples highlight the high degree of control which may be achieved using mixtures of biocontrol agents even in field conditions.

\section{Biological agent additives}

Many additives can enhance the biological control activity of antagonists and salts usually are the most related ones. Thus, the combination of $2 \%$ sodium bicarbonate with the yeast antagonist Candida oleophila enhanced significantly its biocontrol performance (curative and protective effect) against fungi rot diseases caused by Botrytis, Penicillium, Monilinia and Rhizopus in apple and peach (DROBY et al., 2003). Similarly, a sugar analogue (2-deoxy-dscp-glucose) has also demonstrated the capacity to increase efficacy. The bioagent Candida saitoana supplemented with $0.2 \%$ 2-deoxy-D-glucose was more effective in controlling decay of apple, orange, and lemon caused by Botrytis cinerea, Penicillium expansum, and $P$. digitatum than either $C$. saitoana or the application of a $0.2 \%$ solution of 2-deoxy-D-glucose alone (EL GHAOUTH et al., 2000).

Other additives such as ethanol, silicon, nisin and chitosan, have been reported to enhance the quality and control efficacy of different biocontrol agents (JANISIEWICZ; CONWAY, 2010).

\section{Integration of biological control with other methods}

Some examples of integration of the biological control with others postharvest methods have been proposed. Thus, modified storage conditions, physical and chemical treatments have been used in combination with biocontrol agents and their additive or synergic effect have increased the level of disease control (MARI; NERI; BERTOLINI, 2007; JANISIEWICZ; CONWAY, 2010). Integrating the antagonistic Cryptococcus laurentii with $104 \mathrm{ppm}$ of thiabendazole improved the control of grey mould caused by Botrytis cinerea on apples (LIMA et al., 2006). Similarly, the application of the same antagonist in combination with 25 ppm imazalil or 50 ppm kresoximmethyl resulted in less decay caused by Alternaria alternata and Monilinia fructicola (compared with separate applications) on jujube fruits stored in a controlled atmosphere (QIN; TIAN, 2004).

Besides, to enhance the bioefficacy of microbial antagonists the attractive approache which may be used in a large scale in the future is the improvement of genetic traits involved with the ability of the antagonist to inhibit the establishment and the development of the pathogen as well as the mycotoxin production. Some techniques to manipulate the antagonists have already been described using conventional mutagenesis (ionizing radiations, mutagenic chemicals, fungicide or antibiotic exposure) or sexual recombination, through protoplast fusion or genetic transformation (SPADARO; GULLINO, 2004).

\section{CONCLUDING REMARKS}

In this paper, we reviewed the major trends on biological control which has been considerated an effective approach to reduce the postharvest losses caused by store fungi and mycotoxin contamination. Probably, the most positive trait of this strategy is the reduction of pesticides use which brings relevant prospects to environmental and human health (JANISIEWICZ; KORSTEN 2002). In addition, unlike chemical pesticides the biocontrol agents usually offer disease management alternatives using more than one mechanism of action (FRAVEL, 2005). This characteristic confers several advantages on the pest control mainly due to a lower probabity to select resistant phytopathogenic strains.

Generally, studies related on the use of microorganisms as biocontrol agents focus only on efficacy, ignoring the lack of toxic residue and the effect on the food quality (ZHANG et al., 2010). Yeast used as biological microrganisms in coffee crop have been reported to suppress mold incidence and mycotoxin contamination apart from improving the coffee cup quality and aroma (VELMOUROUGANE et al., 2011). Other secondary benefits, such as enhancement of fruit firmness and longer shelf-life, have also been correlated with biocontrol agents (VIOLANTEet al., 2009). 
However, it is unrealistic to imagine that biological control alone will solve all problems of storage fungi and mycotoxin contamination. Nevertheless, the use of antagonist mixtures or combine them with other methods can easily overcome many difficulties found during the crop development. Therefore, it is increasingly clear the trend and necessity of inserting the biocontrol agents in a integrated pest management. Indeed, many efforts have been made to develop a whole biological control programs (ESHEL et al., 2009; JANISIEWICZ; CONWAY, 2010). Finally, the benefits of antagonists utilization outweigh their capacity to reduce the storage fungi inoculums or mycotoxin contamination. Since they are virtually nontoxic to non-target organisms, biocontrol agents have become largely accepted by 'eco-friendly' consumers. This new economical niche is fiercely influencing the farmers to include the biological control as an alternative for chemical pesticides. Because of that, it can be expected that the participation of biocontrol products on the agricultural chemical sales will increase in a near future.

\section{ACKNOWLEDGMENTS}

The authors are in debt to FAPESP (Fundação de Amparo à Pesquisa do Estado de São Paulo) for providing fellowships and research funds to TDZ (grants 11/50243-1 and 11/14333-6) and to CNPq for providing assistantships to the first and fifth authors.

\section{LITERATURE CITED}

ABRAHAM, A.O.; LAING, M.D.; BOWER, J.P. Isolation and in vivo screening of yeast and Bacillus antagonists for the control of Penicillium digitatum of citrus fruit Biological Control, Orlando, v.53, n.1, p.32-38, Dec. 2010.

AGRIOS, G. N. Plant pathology. New York: Academic Press, 2005. 922 p.

ASAO, T. et al. Aflatoxins B and G. Journal of the American Chemical Society, Washington, v.85, n.11, p.1706-1707, Mar.1963.

BAKER, K.J.; COOK, R.J. Biological Control of Plant Pathogens. San Francisco: Freeman, 1974. 433p.

BLANDINO, M. et al. Influence of agricultural practices on Fusarium infection, fumonisin and deoxynivalenol contamination of maize kernels. World Mycotoxin Journal, Bilthoven, v.2, n.4, p.409-418, Nov. 2009.
DAL BELLO, G. et al. Biocontrol of postharvest grey mould on tomato by yeasts. Journal of Phytopathology, Berlin, v.156, n.5, p.257-263, Aug. 2008.

BENNETT, J.W; KLICH, M. Mycotoxins. Clinical Microbiology Reviews, Washington, v.16, n.5, p.497-516, Jul. 2003.

BHATNAGAR, D. et al. Understanting the genetics of regulation of aflatoxina production and Aspergillus flavus development. Mycopathologia, Dordrecht, v.162, n.3, p.155-166, Sep. 2006.

BONATERRA, A. et al. Biological control of Monilinia laxa and Rhizopus stolonifer in postharvest of stone fruit by Pantoea agglomerans EPS125 and putative mechanisms of antagonism. International Journal of Food Microbiology, Amsterdam, v.84, n.1, p.93-104, Aug. 2003.

BRODERS, K.D. et al. Characterization of Pythium spp. associated with corn and soybean seed and seedling disease in Ohio. Plant Disease, Saint Paul, v.91, n.6, p.127-735, Jun. 2007.

CALDAS, E.D; SILVA, S.C.; OLIVEIRA, J.N. Aflatoxins and ochratoxin A in food and the risks to human health. Revista de Saúde Pública, São Paulo, v.36, n.3, p.319-323, Mar. 2002.

CALVO, A.M. et al. Relationship between secondary metabolism and fungal development. Microbiology and Molecular Biology Reviews, Washington, v.66, n.3, p.447-459, Sep. 2002.

CALVO, J. et al. Improvement in the biocontrol of postharvest diseases of apples with the use of yeast mixtures. Biocontrol, Dordrecht, v.48, n.5, p.579-593, Out. 2003.

CAST. Council for Agricultural Science and Technology. Mycotoxins: Risck in Plant, Animal and Human Systems. Task Force Report n ${ }^{\circ}$ 139, Ames, Iowa, USA, 2003.

CHAYTOR, A.C. et al. Occurrence and decontamination of mycotoxins in swine feed. AsianAust. Journal of Animal Science, Seoul, v.24, n.5, p.723-738, May 2011. 
CONWAY, W.S. et al. Improving biocontrol using antagonist mixtures with heat and/or sodium bicarbonate to control postharvest decay of apple fruit. Postharvest Biology and Technology, Amsterdam, v.36, n.3, p.235-244, Jan. 2005.

COTTY, P.J.; MELLON, J.E. Ecology of aflatoxin producing fungi and biocontrol of aflatoxin contamination. Mycotoxin Research, New Orleans, v.22, n.2, p.110-117, Jun. 2006.

CREPPY, E. E. Update of survey, regulation and toxic of mycotoxins in Europe. Toxicology Letters, Amsterdam, v.127, n.1-3, p.19-29, Feb. 2002.

DE CAL, A. et al. Population dynamics of Epicoccum nigrum, a biocontrol agent against brown rot in stone fruit. Journal of Applied Microbiology, Malden, v.106, n.2, p.592-605, Feb. 2009.

DORNER, J.W. Biological control of aflatoxin contamination in corn using a nontoxigenic strain of Aspergillus flavus. Journal of Food Protection, Des Moines, v.72, n.4, p.801-804, Apr. 2009.

DORNER, J.W. Biological control of aflatoxin contamination of crops. Toxin Reviews, Philadelphia, v.23, n.2-3, p.425-450, Aug. 2004.

DORNER, J.W. Management and prevention of mycotoxins in peanuts. Food Additives And

Contaminants, Oxon, v.25, n.2, p.203-208, Feb. 2008.

DORNER, J.W.; COLE, R.J.; Blankenship, P.D. Effect of inoculum rate of biological control agents on preharvest aflatoxin contamination of peanuts. Biological Control, Orlando, v.12, n.3, p.171-176, Jul. 1998.

DROBY, S. et al. Influence of food additives on the control of postharvest rots of apple and peach and efficacy of the yeast-based biocontrol product aspire. Postharvest Biology and Technology, Amsterdam, v.27, n.2, p.127-135, Feb. 2003.

EDWARDS, S.G. et al. Quantification of trichotheceneproducing Fusarium species in harvested grain by competitive PCR to determine efficacies of fungicides against Fusarium head blight of winter wheat. Applied and Environment Microbioloy, Washington, v.67, n.4, p.1575-1580, Apr. 2001.
EUROPEANFOOD SAFETY AUTHORITY - EFSA.

Review of mycotoxin-detoxifying agents used as feed additives: mode of action, efficacy and feed/food safety. Sci. Report, Parma, Italy, 2009. Available in: <http:// www.efsa.europa.eu/en/scdocs/doc/22e.pdf $>$ Accessed on 26 Aug. 2012.

EL-GHAOUTH, A. et al. Improved control of apple and citrus decay with a combination of Candida saitoana with 2-deoxy-D-glucose. Plant Disease, Saint Paul, v.84, n.3, p.249-253, Mar. 2000.

ESHEL, D. et al. Combining physical, chemical and biological methods for synergistic control of postharvest diseases: A case study of Black Root Rot of carrot. Postharvest Biology and Technology, Amsterdam, v.54, n.1, p.48-52, Apr. 2009.

FOOD AND AGRICULTURE ORGANIZATION - FAO. (2004) Worldwide regulations for mycotoxins in food and feed in 2003. Roma. Available online: <http:// www.fao.org/docrep/007/y5499e/ y5499e07.htm\#TopOfPage> Accessed on 12 July 2012.

FILTENBORG, O.; FRISVAD, J.C.; THRANE, U. Moulds in food spoilage. Food Microbiology, Amsterdam, v.33, n.1, p.85-102, Nov. 1996.

FRAVEL, D.R. Commercialization and implementation of biocontrol. Annual Review of Phytopathology, Palo Alto, v.43, p.337-59, Jul. 2005.

GOODFELLOW, M. et al. Verrucosispora maris sp. Nov., a novel deep-sea actinomycete isolated from a marine sediment which produces abyssomicins. Antonie Van Leeuwenhoek, Dordrecht, v.101, n.1, p.185-193, Jan. 2012.

HOOPWOOD, D.A.; SHERMAN, D.H. Molecular genetics of polyketides and its comparison to fatty acid biosynthesis. Annual Review of Genetics, Palo Alto, v.34, p.37-62, 1990.

HULVOVÁ, H. et al. Parasitic fungus Claviceps as a source for biotechnological production of ergot alkaloids - Review article. Biotechnology Advances (in press), Jan. 2012. Available in: <http:// www.sciencedirect.com/science/article/pii/ S0734975012000079> Accessed on 28 Jul. 2012. 
HUA, S.S.T.; BAKER, J.L.; FLORES-ESPIRITU, M. Interactions of saprophytic yeasts with a nor mutant of Aspergillus nidulans. Applied and Environmental Microbiology, Washington, v.65, n.5, p.2738-2740. May 1999.

HUSSEIN, H.S.; BRASEL, J.H. Toxicity, metabolism and impat of mycotoxins on humans and animals. Toxicology, Clare, v.167, n.2, p.101-134, Oct. 2001.

IRTWANGE, S.V. Application of biological control agents in pre-and postharvest operations. Agricultural Engineering International, Hokkaido, v.8, n.3, p.1-12, Feb. 2006.

\section{ISAKEIT, T. Prevention of aflatoxin contamination of} corn using af-36 or afla-guard®. Available in: <http:// amarillo.tamu.edu/files/2010/11/

09_FS_FC004_Atoxigenic.pdf $>$ Accessed on 28 Jul. 2012.

JANISIEWICZ, W.J.; CONWAY, W.S. Combining biological control with physical and chemical treatments to control fruit decay after harvest. Stewart Postharvest Review, Redhill, v.6, n.1, p.2-16, Mar. 2010.

JANISIEWICZ, W.J.; KORSTEN, L. Biological control of postharvest diseases of fruits. Annual Review of Phytopathology, Palo Alto, v.40, n.24, p.411-441, Feb. 2002.

JUNG-IL, C.; HONG, K.W.; KANG, K.J. Control of aflatoxin production of Aspergillus flavus by inhibitory action of antagonistic bacteria. Journal of Microbiology and Biotechnology, Singapore, v.10, n.2, p.154-160, Apr. 2000 .

KÖPPEN, R. et al. Determination of mycotoxins in foods: current state of analylical methods and limitations. Applied Microbiology and Biotechnology, New York, v.86, n.6, p.1595-1612, May 2010.

KORSTEN, L. Advances in control of postharvest diseases in tropical fresh produce. International Journal of Postharvest Technology and Innovation, Umezuruike Linus, v.1, n.1, p.48-61, 2006.

LACKNER, G.; MARTINEZ, L.P.P.; HERTWECK, C. Endofungal bacteria as producers of mycotoxins. Trends in Microbiology, London, v.17, n.12, p.570-576, Dec. 2009.
LAHLALI, R. Control of apple blue mold by the antagonistic yeast Pichia anomala strain K: Screening of UV protectants for preharvest application. Plant Disease, Saint Paul, v.95, n.3, p.311-316, Mar. 2011.

LAITILA, A. et al. Yeasts isolated from industrial maltings can suppress Fusarium growth and formation of gushing factors. Journal of Industrial Microbiology \& Biotechnology, Heidelberg, v.34, n.11, p.701-713, Nov. 2007.

LIMA, G. et al. Integration of biocontrol yeast and thiabendazole protects stored apples from fungicide sensitive and resistant isolates of Botrytis cinerea.

Postharvest Biology and Technology, Amsterdam, v.40, n.3, p.301-307, Apr. 2006.

MAGAN, N.; ALDRED, D. Post-harvest control strategies: minimizing mycotoxins in the food chain. International Journal of Food Microbiology. Amsterdam, v.119, n.1-2, p.131-139, Oct. 2007.

MANSO, T.; NUNES, C. Metschnikowia andauensis as a new biocontrol agent of fruit postharvest diseases

Postharvest Biology and Technology, Amsterdam, v.61, n. 1, p.64-71, Apr. 2011.

MARI, M.; NERI, F.; BERTOLINI, P. Novel approaches to prevent and control postharvest diseases of fruit. Stewart Postharvest Review, Redhill, v.3, n.6, p.1-7, Dec. 2007.

MILIÆEVIÆ, D.R.; ŠKRINJAR, M.; BALTIÆ, T. Real and perceived risks for mycotoxin contamination in foods and feeds: Challenges for food safety control. Toxins, Basel, v.2, n.4, p.572-592, Apr. 2010.

MOTOMURA, M. et al. Screening and isolation of antiFusarium moniliforme compounds producing microorganisms from soil and corn. Revista de Microbiologia, São Paulo, v.27, n.4, p.213-217, Out./Dez. 1996.

PAPP, E. et al. Liquid chromatographic determination of aflatoxins. Microchemical Journal, Amsterdam, v.73, n.1-2, p.39-46, Oct. 2002.

PERAICA, M. et al. Toxic effects of mycotoxins in humans. Bulletin of the World Health Organization, Geneva, v.77, n.9, p.754-766, 1999. 
PROCTOR, R.H. et al. Evidence that a secondary metabolic biosynthetic gene cluster has grown by gene relocation during evolution of the filamentous fungus Fusarium. Molecular Microbiology. Malden, v.74, n.5, p.1128-1142, Dec. 2009.

PUSEY, P.L. Antibiosis as mode of action in postharvest biological control, In: WILSON, C.L.; CHALUTZ, E. Biological Control of Postharvest Disease of Fruits and Vegetables, Washington: Workshop Proceedings, Jun. 1991.p.127-141.

QIN, G.Z.; TIAN, S.P. Biocontrol of postharvest diseases of jujube fruit by Cryptococcus laurentii combined with a low dosage of fungicides under different storage conditions. Plant Disease, Saint Paul, v.88, n.30, p.497501, May 2004.

REVERBERI, M. et al. Natural functions of mycotoxins and control of their biosynthesis in fungi. Applied Microbiology and Biotechnology, New York, v.87, n.3, p.899-911, Jul. 2010.

RICHARD, J.L. Some major mycotoxins and their mycotoxicosis - An overview. International Journal of Food Microbiology, Amsterdam, v.119, n.1-2, p.3-10, Jul. 2007.

RICHARD, W.J.; PRUSKY, D. Expression of an antifungal peptide in Saccharomyces: a new approach for biological control of the postharvest disease caused by Colletotrichum coccodes. Phytopathology, Saint Paul, v.92, n.1, p.33-37, Jan. 2002.

SAGAHÓN, I.P. et al. Isolation of bacteria with antifungal activity against the phytopathogenic fungi Stenocarpella Maydis and Stenocarpella macrospora. International Journal of Molecular Sciences. Basel, v.12, n.9, p.5522-5537, Sep. 2011.

SAKUDA, S. et al. Blasticidin A derivatives with highly specific inhibitory activity toward aflatoxin production in Aspergillus parasiticus. Journal of Antibiotics, Tokyo, v.53, n.12, p.1378-1384, Dec.2000b.

SAKUDA, S. et al. Aflastatin A, a novel inhibitor of aflatoxin production of Aspergillus parasiticus, from Streptomyces. Journal of the American Chemical Society, Washington, v.118. n.33, p.7855-7856. Aug. 1996.
SAKUDA, S. et al. Blasticidin A as an inhibitor of aflatoxin production by Aspergillus parasiticus. Journal of Antibiotics, Tokyo, v.53, n.11, p.1265-1271. Nov. 2000a.

SAKUDA, S. et al. Aflastatins: new Streptomyces metabolites that inhibit aflatoxin biosynthesis. In: CUTLER, H.G.; CUTLER, S.J. (Eds.) Biologically active natural products: agrochemicals. Boca Raton. CRC Press, 1999. p.185-199.

SARAVANAKUMAR, D. et al. Detection of enzymatic activity and partial sequence of a chitinase gene in Metschnikowia pulcherrima strain MACH1 used as post-harvest biocontrol agent. European Journal of Plant Pathology, Dordrecht, v.123, n.2, p.183-193, Feb. 2009.

SCHATZMAYR, G; ; et al. Microbiologicals for deactivating mycotoxins. Molecular Nutrition \& Food Research, Weinheim, v.50, n.6, p.543-551, May 2006.

SCHISLER, D.A.; SLININGER, P.J. Microbial selection strategies that enhance the likelihood of developing commercial biological control products. Journal of Industrial Microbiology \& Biotechnology, Hampshire, v.19, n.3, p.172-79, May 1997.

SCHUSTER, R.; MARX, G.; RATHAUPT, M. Analysis of Mycotoxins by HPLC with automated confirmation by spectral library. HP Application Note, Pub. NR. 12- 5091$8692,1993$.

SCOTT, P.M. et al. Ergot alkaloids in grain foods sold in Canada. Journal of AOAC International, Gaithersburg, v.75, n.5, p.773-779, Set./Oct.1992.

SHARMA, R.R.; SINGH, D.; SINGH, R. Biological control of postharvest diseases of fruits and vegetables by microbial antagonists: A review. Biological Control, Orlando, v.50, n.3, p.205-221, Sep. 2009.

SHENASI, M.; AIDOO, K. E.; CANDLISH, A. A. G. Microflora of date fruits and production of aflatoxins at various stage of maturation. International Journal of Food Microbiology, Amsterdam, v.79, n.1-2, p.113-119, Nov. 2002.

SIPICZKI, M. Metschnikowia strains isolated from botrytized grapes antagonize fungal and bacterial growth by iron depletion. Applied and Environment Microbioloy, Washington, v.70, n.10, p.6716-6724, Oct. 2006. 
SPADARO, D.; GULLINO, M.L. State of the art and future prospects of biological control of postharvest fruit diseases. International Journal of Food Microbiology, Amsterdam, v.91, n.2, p.185-194, Mar. 2004.

VEKIRU, E. et al. Cleavage of Zearalenone by Trichosporon mycotoxinivorans to a novel nonestrogenic metabolite. Applied and Environment Microbioloy, Washington, v.76, n.7, p.2353-2359, Apr. 2010.

VELMOUROUGANE, K. et al. Management of Aspergillus ochraceus and Ochratoxin-A contamination in coffee during on-farm processing through commercial yeast inoculation. Biological Control, Orlando, v.57, n.3, p.215-221, Jun. 2011.

VIOLANTE, H.G.M. et al. Fruit texture related changes and enhanced shelf-life through tomato root inoculation with Bacillus subtilis BEB-13BS. Agrociencia, México, v.43, n.6, p.559-567, Jul. 2009.

WELLER, D. M. Biological control of soilborne plant pathogens in the rhizosphere with bacteria. Annual Review of Phytopathology, PaloAlto, v.26, p.379-407, Sep.1988.

WILSON, J.P. et al. Host-specific variation in infection by toxigenic fungi and contamination by mycotoxins in pearl millet and corn. Mycopathologia, Dordrecht, v.161, n.2, p.101-107. Feb. 2006.

YIN, Y. et al. Biological control of aflatoxin contamination of crops. Journal of Zhejiang University. Science B, Hangzhou, v.9, n.10, p.787-792, Oct. 2008.
YOSHINARI, T. et al. Dioctatin A is a strong inhibitor of aflatoxin production by Aspergillus parasiticus. Microbiology, Spencers Wood, v.153, n.8, p.2774-2780, Aug. 2007.

ZHANG, D. et al. Selection and evaluation of new antagonists for their efficacy against postharvest brown rot of peaches. Postharvest Biology and Technology, Amsterdam, v.55, n.3, p.174-181, Mar. 2010.

ZUCCHI, T. D.; MORAES, L. A. B. ; MELO, I. S. . Streptomyces sp. ASBV-1 reduces aflatoxin accumulation by Aspergillus parasiticus in peanut grains. Journal of Applied Microbiology, Malden, v. 105, p. 2153-2160, 2008.

ZUCCHI, T.D; DE MELO, I.S. Controle biológico de fungos aflatoxigênicos. In: BETTIOL, W.; MORANDI, M.A.B. editores. Biocontrole de Doenças de Plantas: Uso e Perspectivas. Jaguariúna - SP: Embrapa, 2009. $1^{\text {a }}$ edição, p.69-74.

ZUCCHI, T.D. et al. Amycolatopsis bartoniae sp. Nov. and Amycolatopsis bullii sp. Nov., mesophilic actinomycetes isolated from arid Australian soils.

Antonie van Leeuwenhoek, Dordrecht, v.102, n.1, p.9198, Jun. 2012b.

ZUCCHI, T.D.; TAN, G.Y.A.; GOODFELLOW, M. Amycolatopsis thermophila sp. Nov. and Amycolatopsis viridis $\mathrm{sp}$. Nov., thermophilic actinomycetes isolated from arid soil. International Journal of Systematic and Evolutionary Microbiology, England v.62, n.1, p.168-172, Jan. 2012a. 